\title{
Powder for Oral Solution Dosage Form
}

National Cancer Institute

\section{Source}

National Cancer Institute. Powder for Oral Solution Dosage Form. NCI Thesaurus. Code C64907.

A powder that yields a solution intended for oral administration following reconstitution. 